Western University

Scholarship@Western

Chemistry Publications

Chemistry Department

8-24-2018

\title{
Multi-stimuli-responsive Self-immolative Polymer Assemblies
}

Rebecca E. Yardley

Western University

Elizabeth R. Gillies

Western University, egillie@uwo.ca

Follow this and additional works at: https://ir.lib.uwo.ca/chempub

Part of the Chemistry Commons

Citation of this paper:

Yardley, Rebecca E. and Gillies, Elizabeth R., "Multi-stimuli-responsive Self-immolative Polymer Assemblies" (2018). Chemistry

Publications. 107.

https://ir.lib.uwo.ca/chempub/107 


\title{
Multi-stimuli-responsive Self-immolative Polymer Assemblies
}

\author{
Rebecca E. Yardley, ${ }^{1}$ Elizabeth R. Gillies*1,2 \\ ${ }^{1}$ Department of Chemistry and the Centre for Advanced Materials and Biomaterials Research, The \\ University of Western Ontario, 1151 Richmond Street, London, ON, Canada, N6A 5B7 \\ ${ }^{2}$ Department of Chemical Engineering, The University of Western Ontario, 1151 Richmond Street, \\ London, ON, Canada, N6A 5B9 \\ Correspondence to: E. R. Gillies (egillie@uwo.ca)
}

Additional Supporting Information may be found in the online version of this article.

\begin{abstract}
Self-immolative polymers (SIPS) undergo depolymerization in response to the cleavage of stimuliresponsive end-caps from their termini. Some classes of SIPs, including polycarbamates, have depolymerization rates that depend on environmental factors such as solvent and $\mathrm{pH}$. In previous work, hydrophobic SIPs have been incorporated into amphiphilic block copolymers and used to prepare nanoassemblies. However, stimuli-responsive hydrophilic blocks have not previously been incorporated. In the current work, we synthesized amphiphilic copolymers composed of a hydrophobic polycarbamate SIP block and a hydrophilic poly(2-dimethylaminoethyl methacrylate) (PDMAEMA) block connected by a UV light-responsive linker end-cap. It was hypothesized that after assembly of the block copolymers into nanoparticles, chain collapse of the PDMAEMA above its lower critical solution temperature (LCST) might change the environment of the SIP block, thereby altering its depolymerization rate. Self-assembly of the block copolymers was performed, and the depolymerization of the resulting assemblies was studied by fluorescence spectroscopy, dynamic light scattering, and NMR spectroscopy. At $20^{\circ} \mathrm{C}$, the system exhibited a selective response to the UV light. At $65{ }^{\circ} \mathrm{C}$, above the LCST of PDMAEMA, the systems underwent more rapid depolymerization, suggesting that the increase in rate arising from the higher temperature dominated over environmental effects arising from chain collapse.
\end{abstract}

KEYWORDS: Self-immolative, Stimuli-responsive, Depolymerization, Self-assembly, Thermoresponsive

\section{INTRODUCTION}

Over the past few decades, there has been significant interest in degradable polymers such as poly(lactic acid), ${ }^{1-4}$ poly(glycolic acid) ${ }^{5-6}$ and polycaprolactone $e^{4,7}$ for a wide range of applications from nanomedicine to compostable consumer products. The degradation rates of these polymers can be controlled to some extent by modifying their chemical structures or chain lengths, but it occurs gradually under all aqueous conditions and may be slower or faster than desired for a given application. To address this limitation, stimuli-responsive polymers that degrade in response to external stimuli have been developed. Stimuli-responsive units or linkages have been incorporated into the 
polymer backbone and later cleaved in response to stimuli causing a breakdown of the polymer. For example, acid-labile acetals and ketals, ${ }^{8-10}$ reduction-sensitive disulfide linkages ${ }^{11-14}$ or photochemically-sensitive units such as coumarin dimers, ${ }^{15-16}$ o-nitrobenzyl esters and carbonates, ${ }^{17-18}$ and 2-diazo-1,2napthoquinones ${ }^{19}$ have been used. However, many stimuli-mediated reactions must occur in these systems in order to completely degrade the polymers.

Self-immolative polymers (SIPs), which depolymerize end-to-end in response to the cleavage of stimuli-responsive end-caps at the polymer termini, were introduced to provide amplified responses to stimuli. ${ }^{20-22}$ The stimulus to which they respond can be easily modified by simply switching the end-cap, while retaining the structure of the polymer backbone. Cleavage of end-caps in response to stimuli such as acid, ${ }^{23}$ reducing agents, ${ }^{24-25}$ heat, $^{26}$ or light ${ }^{24,27-28}$ has been shown to trigger depolymerization. Various SIP backbones have been developed.

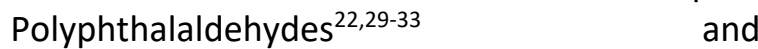
polyglyoxylates ${ }^{27,34-35}$ rely on low ceiling temperatures, which allow them to undergo reversible loss of monomers after end-cap cleavage. Systems such as polycarbamates, ${ }^{36-41}$ poly(benzyl ether)s, ${ }^{42}$ and poly(carbamatethiocarbamate) $\mathrm{s}^{25}$ undergo cyclization and/or elimination reactions that result in their depolymerization to products that are different from the monomers from which they were prepared. The degradation rate of this latter class of SIPs is generally quite sensitive to environmental factors such as $\mathrm{pH}$ and solvent. ${ }^{37,39-40}$

Another class of stimuli-responsive polymers is thermo-responsive polymers, which undergo changes in their physical properties when exposed to changes in temperature. For example, $\quad \operatorname{poly}(N$-isopropylacrylamide) (PNIPAAm) exhibits a lower critical solution temperature (LCST). ${ }^{43-44}$ Below the LCST, the polymer chains are soluble, but above the LCST an entropically driven phase separation occurs.
Another well-studied polymer that has an LCST is poly(2-(dimethylamino)ethyl methacrylate) (PDMAEMA) ${ }^{45-46}$ It differs from PNIPAAm in that it is responsive to both $\mathrm{pH}$ and temperature. The LCST of PDMAEMA is only observed when the $\mathrm{pH}$ of the solution is above the pKa of the polymer ( 7.5). Both PNIPAAm and PDMAEMA have been used in recent years in the preparation of thermo-responsive nanomaterials. ${ }^{47}$

The synthesis of block copolymers is an approach that allows for the combination of two known polymers to create a new polymer with unique properties. Amphiphilic block copolymers can self-assemble in aqueous solution to form a wide variety of morphologies including spherical micelles, vesicles and bilayers. ${ }^{48}$ Previous work has investigated the self-assembly of amphiphilic block copolymers that were prepared by combing a hydrophobic SIP block with a simple non-responsive hydrophilic block such as poly(ethylene glycol) (PEG) and $\operatorname{poly}\left(\mathrm{N}, \mathrm{N}\right.$-dimethylacrylamide). ${ }^{24,35,37,49}$ These copolymers self-assembled to form nanoparticles and vesicles that degraded upon application of the stimulus and depolymerization of the hydrophobic SIP block. To the best of our knowledge, the use of hydrophilic blocks that are also responsive to stimuli has not yet been investigated.

Herein we report the synthesis, self-assembly, and stimuli-responsive depolymerization of block copolymers composed of a hydrophobic self-immolative polycarbamate $(P C B)^{37}$ and a hydrophilic PDMAEMA block, conjugated by a UV light-responsive linker. It was proposed that irradiation should result in depolymerization of the hydrophobic polycarbamate block, leading to disintegration of the copolymer assemblies. Concomitantly, the PDMAEMA block should exhibit responsiveness to $\mathrm{pH}$ and temperature. As the depolymerization of the polycarbamate SIP block is sensitive to its environment, it was hypothesized that collapse of the PDMAEMA chains around the assembly cores might hinder water access to the cores, thereby modulating 
the rate of the polycarbamate depolymerization (Figure 1).

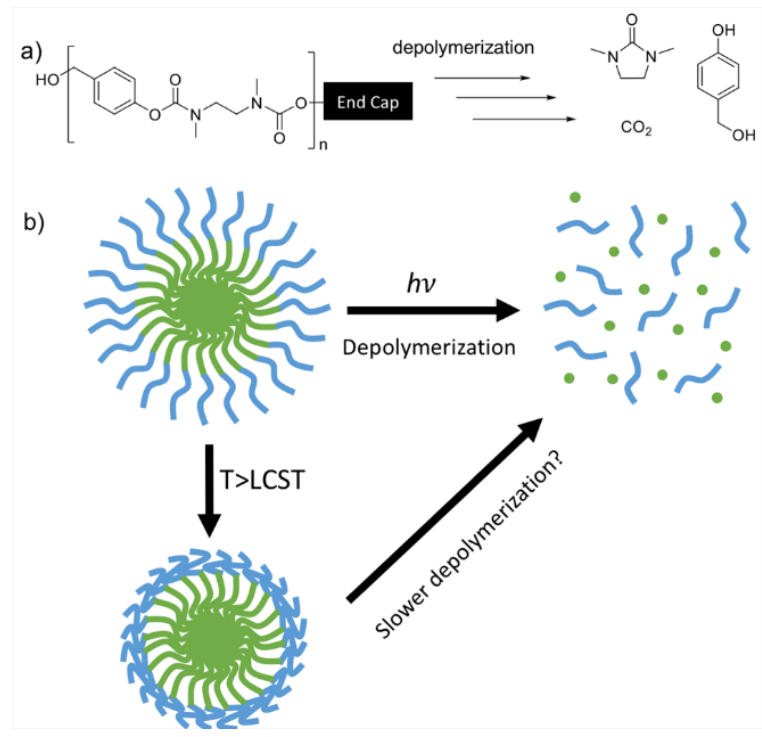

FIGURE 1 a) Schematic of PCB block breakdown and b) Initially proposed behaviour of PCBPDMAEMA block copolymer assemblies.

\section{EXPERIMENTAL}

\section{General materials}

Compounds $1,{ }^{27} 3,^{50} 5,{ }^{37}$ and $6^{51}$ were prepared as previously reported. 3-Bromo-1-propanol, 2bromo-2-methylpropinyol bromide and 4nitrophenol chloroformate were purchased from AK Scientific. 1,1,4,7,10,10Hexamethyltriethylenetetramine (HMTETA) was purchased from Alfa Aesar. Copper (I) bromide, sodium azide and 2-(dimethylamino)ethyl methacrylate were purchased from SigmaAldrich and used without further purification unless otherwise noted. Anhydrous dimethylformamide (DMF) was obtained from a solvent purification system equipped with aluminum oxide columns. Pyridine, $\mathrm{NEt}_{3}$ and $\mathrm{CH}_{2} \mathrm{Cl}_{2}$ were distilled from $\mathrm{CaH}_{2}$. Column chromatography was performed using silica gel (0.063-0.200 mm particle size, 70-230 mesh).

\section{General procedures}

Unless otherwise stated, all reactions were performed under a $\mathrm{N}_{2}$ atmosphere using flame or oven dried glassware. Dialyses were performed using Spectra/Por regenerated cellulose membranes. ${ }^{1} \mathrm{H}$ NMR spectra were obtained at $600 \mathrm{MHz}$ or $400 \mathrm{MHz}$ using Varian INOVA spectrometers. ${ }^{13} \mathrm{C}$ NMR spectra were obtained at $150 \mathrm{MHz}$ using a Varian Inova spectrometer. A Thermo Scientific DFS (Double Focusing Sector) mass spectrometer, utilizing a reversed Nier Johnson geometry was used for high resolution mass spectrometry. Ultrapure deionized water was obtained from the Barnstead EASYpure II system. Size exclusion chromatography (SEC) was carried out at a flow rate of $1 \mathrm{~mL} / \mathrm{min}$ in DMF with $10 \mathrm{mM} \mathrm{LiBr}$ and $1 \%$ (v/v) $\mathrm{NEt}_{3}$ at $85^{\circ} \mathrm{C}$ using a Waters 515 HPLC pump and Waters Temperature Control Module II equipped with a Wyatt Optilab T-rEX refractometer and two PLgel $5 \mu \mathrm{m}$ mixed-D (300 $\mathrm{mm} \times 7.5 \mathrm{~mm}$ ) columns from Polymer Laboratories by Varian connected in series. The calibration was performed using poly(methyl methacrylate standards) (PMMA) standards. Dynamic light scattering (DLS) was performed using a Zetasizer Nano ZS instrument from Malvern Instruments at $25^{\circ} \mathrm{C}$ at a concentration of $0.8 \mathrm{mg} / \mathrm{mL}$ of polymer assemblies. Transmission electron microscopy (TEM) imaging was performed using a Phillips CM10 Microscope operating at an acceleration voltage of $80 \mathrm{kV} .10 \mu \mathrm{L}$ of micelle suspension $(0.8$ $\mathrm{mg} / \mathrm{mL}$ ) was placed onto a copper grid. After 5 min, the liquid was wicked away using strips of Fisherbrand $^{\mathrm{TM}}$ Qualitative-Grade Filter Paper Circles and the grid was air-dried for $2 \mathrm{~h}$. Fluorescence spectra were obtained using a QM4 SE spectrometer from Photon Technology International (PTI) equipped with both excitation and emission monochromators. UV-visible spectra were obtained on a Varian UV/vis Cary 300 spectrophotometer equipped with a Varian Cary 8453 Temperature Controller. Infrared (IR) spectra were obtained on a PerkinElmer Spectrum Two FTIR Spectrometer using the attenuated total reflectance accessory.

\section{Synthesis of end-cap 2}


Compound $1^{27}$ (1.20 g, $5.12 \mathrm{mmol}, 1.00$ equiv.) was dissolved in dry pyridine $(1.30 \mathrm{~mL}, 15.9$ mmol, 3.10 equiv.) and dry THF $(25 \mathrm{~mL})$. 4Nitrophenyl chloroformate $(2.07 \mathrm{~g}, 10.3 \mathrm{mmol}$, 2.00 equiv.) was added and the reaction was stirred for $3 \mathrm{~h}$. The solvent was removed in vacuo and the resulting residue was dissolved in ethyl acetate (EtOAc) $(50 \mathrm{~mL})$. The solution was then washed with $1 \mathrm{M} \mathrm{HCl}(50 \mathrm{~mL})$ then the aqueous layer was extracted with EtOAc $(3 \times 50 \mathrm{~mL})$. The organic layers were combined and dried with $\mathrm{MgSO}_{4}$ and concentrated. The product was purified using silica gel chromatography with 1:1 hexanes:EtOAc as the eluent to yield a pale yellow solid $(1.64 \mathrm{~g})$. Yield: $81 \%$. ${ }^{1} \mathrm{H}$ NMR (600 $\mathrm{MHz}, \mathrm{CD}_{3} \mathrm{CN}, \delta, \mathrm{ppm}$ ): 8.55 (s, $1 \mathrm{H}$ ), 8.30 (d, $J=9.2$ $\mathrm{Hz}, 2 \mathrm{H}), 8.18(\mathrm{~d}, J=6.0 \mathrm{~Hz}, 1 \mathrm{H}), 7.87(\mathrm{~d}, J=7.8$ $\mathrm{Hz}, 1 \mathrm{H}), 7.61(\mathrm{br} \mathrm{s}, 1 \mathrm{H}), 7.48(\mathrm{~d}, J=9.2,2 \mathrm{H}), 5.71$ $(\mathrm{s}, 2 \mathrm{H}), 4.16(\mathrm{~d}, J=6.0 \mathrm{~Hz} 2 \mathrm{H}), 2.13(\mathrm{~s}, 1 \mathrm{H}) \cdot{ }^{13} \mathrm{C}$ NMR (150 MHz, acetonitrile- $\left.D_{3}, \delta, p p m\right): 169.39$, $160.80,157.54,152.70,151.11,140.49,139.08$, 137.69, 134.93, 130.78, 129.31, 127.58, 85.20, 76.47, 72.17, 34.18. IR $\left(\mathrm{cm}^{-1}\right): 3277,3114,3081$, 2920, 2852, 2129, 1749, 1613, 1588, 1517. MS $(\mathrm{m} / \mathrm{z})$ : calcd for $\mathrm{C}_{18} \mathrm{H}_{13} \mathrm{~N}_{3} \mathrm{O}_{8}, 399.07026$; found, $399.06970[\mathrm{M}]^{+}$.

\section{Synthesis of end-cap 4}

In a dry round bottom flask, compound $3^{50}$ (1.17 $\mathrm{g}, 7.20 \mathrm{mmol}, 1.00$ equiv.), pyridine $(2.30 \mathrm{~mL}$, $28.8 \mathrm{mmol}, 4.00$ equiv.) and dry $\mathrm{CH}_{2} \mathrm{Cl}_{2}(50 \mathrm{~mL})$ were combined and stirred for $10 \mathrm{~min}$. 4Nitrophenyl chloroformate $(2.90 \mathrm{~g}, 14.4 \mathrm{mmol}$, 2.00 equiv.) was added and the reaction was stirred for $2 \mathrm{~h}$. The mixture was then filtered to remove solids. The filtrate was washed with $1 \mathrm{M}$ $\mathrm{HCl}(50 \mathrm{~mL})$ and water $(2 \times 50 \mathrm{~mL})$, dried with $\mathrm{MgSO}_{4}$, and concentrated. The crude product was dissolved in $\mathrm{CH}_{2} \mathrm{Cl}_{2}(20 \mathrm{~mL})$ and imidazole (1.63 g, $21.6 \mathrm{mmol}, 3.00$ equiv.) was added. The resulting mixture was stirred for $30 \mathrm{~min}$, then passed through a silica plug. The filtrate was concentrated to yield white crystals $(2.12 \mathrm{~g})$. Yield: $94 \% .{ }^{1} \mathrm{H}$ NMR (600 MHz, $\left.\mathrm{CDCl}_{3}, \delta, \mathrm{ppm}\right)$ : $8.27(\mathrm{~d}, J=10.8 \mathrm{~Hz}, 2 \mathrm{H}), 7.41-7.36(\mathrm{~m}, 4 \mathrm{H}) 7.01$ (d, J = 8.9 Hz, 2H), $5.24(\mathrm{~s}, 2 \mathrm{H}), 4.72(\mathrm{~s}, 2 \mathrm{H}), 2.53$ (s, $1 \mathrm{H}) .{ }^{13} \mathrm{C}$ NMR $\left(150 \mathrm{MHz}, \mathrm{CDCl}_{3}, \delta, \mathrm{ppm}\right)$ :
$158.61,155.99,152.90,145.82,131.08,127.68$, $125.73,122.22,115.57,78.68,76.24,71.21$, 56.26. IR $\left(\mathrm{cm}^{-1}\right): 3380,3304,3126,3080,2949$, 1776, 1645, $1521 \mathrm{~cm}^{-1}$. MS $(\mathrm{m} / \mathrm{z})$ : calcd for $\mathrm{C}_{18} \mathrm{H}_{13} \mathrm{~N}_{3} \mathrm{O}_{8}$, 327.07429; found, 327.07498 [M] ${ }^{+}$.

Synthesis of $\mathrm{PCB}_{u v}$ and general procedure for synthesis of the self-immolative block

Monomer precursor $5^{37}$ (2.04 g, $4.04 \mathrm{mmol}, 1.00$ equiv.) was dissolved in 1:1 TFA: $\mathrm{CH}_{2} \mathrm{Cl}_{2}$ (dry) and the reaction mixture was stirred at room temperature under $\operatorname{Ar}$ for $2 \mathrm{~h}$. The solvent was removed via a stream of Ar gas. Additional dry $\mathrm{CH}_{2} \mathrm{Cl}_{2}(5 \mathrm{~mL})$ was added and removed again to ensure all TFA had been removed. The flask was then placed under vacuum to remove all residual solvent. The resulting monomer was dissolved in 1:3 dry THF:Toluene $(24 \mathrm{~mL})$ and the solution was cooled to $0{ }^{\circ} \mathrm{C}$. End-cap 2 was added (79.8 $\mathrm{mg}, 0.2 \mathrm{mmol}, 0.05$ equiv.), followed by $\mathrm{NEt}_{3}$ (7.04 mL, 50.5 mmol, 12.5 equiv.) and 4(dimethylamino)pyridine (DMAP). The reaction was warmed to room temperature and stirred for $24 \mathrm{~h}$. The solution was then diluted with $\mathrm{CH}_{2} \mathrm{Cl}_{2}(50 \mathrm{~mL})$, washed with $1 \mathrm{M} \mathrm{HCl}(50 \mathrm{~mL})$ and $10 \% \mathrm{Na}_{2} \mathrm{CO}_{3}(2 \times 50 \mathrm{~mL})$. The organic layer was dried over $\mathrm{MgSO}_{4}$ and the solvent was removed in vacuo to provide a yellow solid. The crude polymer was further purified by dialysis using a $3.5 \mathrm{~kg} / \mathrm{mol}$ molecular weight cut-off (MWCO) membrane against DMF followed by ultrapure deionized water over $24 \mathrm{~h}$. The sample was lyophilized to afford the product as a white powder (979 mg). Yield: 49\%. ${ }^{1} \mathrm{H}$ NMR $(600 \mathrm{MHz}$, $\left.\mathrm{CDCl}_{3}, \delta, \mathrm{ppm}\right): 8.50(\mathrm{~s}, 1 \mathrm{H}), 8.18-7.87(\mathrm{~m}, 2 \mathrm{H})$, 7.38-7.24 (m, $40 \mathrm{H}), 7.11-7.04(\mathrm{~m}, 35 \mathrm{H}), 5.56(\mathrm{~s}$, $2 \mathrm{H}), 5.13-5.08(\mathrm{~m}, 37 \mathrm{H}), 4.17(\mathrm{~s}, 2 \mathrm{H}), 3.69-3.40$ $(\mathrm{m}, 76 \mathrm{H}), 3.12-2.88(\mathrm{~m}, 135 \mathrm{H}), 2.28(\mathrm{~s}, 1 \mathrm{H}) . \mathrm{IR}$ $\left(\mathrm{cm}^{-1}\right): 2962,1694,1505$. SEC: $\mathrm{M}_{\mathrm{n}}=4640 \mathrm{~g} / \mathrm{mol}$, $\mathrm{M}_{\mathrm{w}}=1.07 \mathrm{~kg} / \mathrm{mol}, \oplus=2.31$.

\section{Synthesis of $\mathrm{PCB}_{\text {con }}$}

This polymer was synthesized by the same procedure as described above for PCB $_{u v}$ except that end-cap 4 was used $(65.4 \mathrm{mg}, 0.2 \mathrm{mmol}$, 0.05 equiv.). The product was obtained as a white powder (1.04 g). Yield: 51\%. ${ }^{1}$ H NMR (600 
$\left.\mathrm{MHz}, \mathrm{CDCl}_{3}, \delta, \mathrm{ppm}\right):$ 7.38-7.25 (m, $\left.52 \mathrm{H}\right), 7.11-$ $7.04(\mathrm{~m}, 39 \mathrm{H}), 7.05-7.03(\mathrm{~m}, 2 \mathrm{H})$, 5.13-5.08 $(\mathrm{m}$, $40 \mathrm{H}), 4.69(\mathrm{~s}, 2 \mathrm{H}), 3.69-3.40(\mathrm{~m}, 79 \mathrm{H}), 3.12-2.88$ $(\mathrm{m}, 154 \mathrm{H}), 2.54(\mathrm{~s}, 1 \mathrm{H}) . \quad$ IR $\left(\mathrm{cm}^{-1}\right):$ 2961, 1690, 1510. SEC: $M_{n}=5400 \mathrm{~g} / \mathrm{mol}, M_{w}=11300 \mathrm{~g} / \mathrm{mol}$, $\bigoplus=2.11$.

\section{Synthesis of PDMAEMA-N $\mathrm{N}_{3}$}

2-(Dimethylamino)ethyl methacrylate (DMAEMA) was passed through a neutral alumina plug to remove the inhibitor. In a Schlenk flask, DMAEMA (5.00 g, $31.8 \mathrm{mmol}, 40.0$ equiv.), HMTETA ( $0.44 \mathrm{~mL}, 0.80 \mathrm{mmol}, 1$ equiv.) and $\mathrm{CuBr}$ (114 mg, $0.80 \mathrm{mmol}, 1$ equiv.) were dissolved in 1,3-dichlorobenzene (4 mL) and degassed by bubbling $\mathrm{N}_{2}$ through the system for $30 \mathrm{~min}$. In a separate flask, a $0.8 \mathrm{M}(200 \mathrm{mg} / \mathrm{mL})$ solution of initiator 6 in 1,3-dichlorobenzene was prepared and degassed for $30 \mathrm{~min}$. The Schlenk flask was heated to $50{ }^{\circ} \mathrm{C}$. The initiator solution ( $1.0 \mathrm{~mL}, 0.80 \mathrm{mmol}, 1.0$ equiv.) was added to the Schlenk flask via a degassed syringe once $50{ }^{\circ} \mathrm{C}$ was achieved and the reaction was stirred for 55 min. The flask was then cooled to $-78^{\circ} \mathrm{C}$, the stopper was removed, and air was bubbled through the solution to quench the polymerization. The solvent was removed in vacuo, then the product was redissolved in THF and passed through a neutral alumina plug to remove copper. The polymer was then precipitated from THF into hexanes three times to yield the pure final product, a clear, colourless solid. (3.43 g). Yield: $67 \%$. ${ }^{1} \mathrm{H}$ NMR $(600 \mathrm{MHz}$, $\left.\mathrm{CDCl}_{3}, \delta, \mathrm{ppm}\right): 4.26(\mathrm{t}, J=5.85 \mathrm{~Hz}, 2 \mathrm{H}), 4.07(\mathrm{~m}$, $69 \mathrm{H}), 3.39(\mathrm{t}, J=6.79 \mathrm{~Hz}, 2 \mathrm{H}), 2.75-2.59(\mathrm{~m}, 98$ H), 2.39-2.25 (m, $200 \mathrm{H}), 2.01-1.82(\mathrm{~m}, 64 \mathrm{H})$, 1.14-0.87 (m, $100 \mathrm{H}) . \mathrm{IR}\left(\mathrm{cm}^{-1}\right)$ : 2948, 2863, 2821, 2769, 2098, 1723, 1517. SEC: $M_{n}=5310 \mathrm{~g} / \mathrm{mol}$, $\mathrm{M}_{\mathrm{w}}=6170 \mathrm{~g} / \mathrm{mol}, \emptyset=1.16$.

Synthesis of PCBuv-PDMAEMA and general procedure for the $\mathrm{Cu}(\mathrm{I})$-assisted azide-alkyne cycloaddition (CuAAC) of self-immolative block and PDMAEMA

In a Schlenk flask, PCBuv (170 mg, 0.02 mmol, 1.0 equiv.), PDMAEMA- $\mathbf{N}_{\mathbf{3}}$ (175 $\mathrm{mg}, 0.03 \mathrm{mmol}, 1.2$ equiv.), and HMTETA (46 mg, $0.20 \mathrm{mmol}, 10$ equiv.) were dissolved in DMF (10 mL). 3 cycles of freeze-pump-thaw were performed. $\mathrm{CuBr}$ (15 $\mathrm{mg}, 0.1 \mathrm{mmol}, 5.0$ equiv.) was then added and the reaction mixture was heated at $50{ }^{\circ} \mathrm{C}$ for 17 h. The solution was then cooled to room temperature and passed through a neutral alumina plug to remove most of the copper. The product was then dialyzed using a $10 \mathrm{~kg} / \mathrm{mol}$ MWCO membrane against DMF, water with EDTA $(1.0 \mathrm{~g} / \mathrm{L}$, adjusted to $\mathrm{pH} 8.0$ by the addition of $\mathrm{NaOH}$ pellets), and finally ultrapure deionized water. The product was then lyophilized to provide a white solid (251 mg). Yield: $76 \% .{ }^{1} \mathrm{H}$ NMR $\left(600 \mathrm{MHz}, \mathrm{CDCl}_{3}, \delta, \mathrm{ppm}\right):$ 7.37-7.23 (m, 42 H), 7.12-7.04 (m, $40 \mathrm{H})$, 5.11-5.04 $(\mathrm{m}, 43 \mathrm{H}), 4.67$ $(\mathrm{m}, 2 \mathrm{H}), 4.19(\mathrm{~s}, 2 \mathrm{H}), 4.15-3.87(\mathrm{~m}, 145 \mathrm{H}), 3.69-$ $3.40(\mathrm{~m}, 91 \mathrm{H}), 3.12-2.88(\mathrm{~m}, 173 \mathrm{H}), 2.57(\mathrm{~m}$, $147 \mathrm{H}), 2.29(\mathrm{~m}, 440 \mathrm{H}), 2.01-1.73(\mathrm{~m}, 240 \mathrm{H})$, 1.14-0.89 (m, 229 H). IR $\left(\mathrm{cm}^{-1}\right): 2963,2881,2846$, 2785, 1718, 1701, 1687, 1513. SEC: $M_{n}=9420$ $\mathrm{g} / \mathrm{mol}, \mathrm{M}_{\mathrm{w}}=1.64 \mathrm{~kg} / \mathrm{mol}, \emptyset=1.74$.

\section{Synthesis of $\mathrm{PCB}_{\text {CON-PDMAEMA }}$}

This polymer was synthesized by the same procedure as described above for $\mathbf{P C B}_{\text {uv- }}$ PDMAEMA except that PCB con $(250 \mathrm{mg}, 0.2$ mmol, 1.0 equiv.) was used. The product was obtained as a white powder (380 mg). Yield: 74\%. ${ }^{1} \mathrm{H}$ NMR $\left(600 \mathrm{MHz}, \mathrm{CDCl}_{3}, \delta, \mathrm{ppm}\right):$ 7.38$7.24(\mathrm{~m}, 36 \mathrm{H}), 7.11-7.04(\mathrm{~m}, 37 \mathrm{H}), 5.13-5.04(\mathrm{~m}$, $38 \mathrm{H}), 4.41(\mathrm{~s}, 2 \mathrm{H}), 4.10-3.90(\mathrm{~m}, 96 \mathrm{H}), 3.69-3.40$ $(\mathrm{m}, 77 \mathrm{H}), 3.1-2.78(\mathrm{~m}, 149 \mathrm{H}), 2.62-2.46(\mathrm{~m}, 94$ $\mathrm{H}), 2.29-2.15(\mathrm{~m}, 290 \mathrm{H}), 2.01-1.56(\mathrm{~m}, 140 \mathrm{H})$, 1.28-0.85 (m, $151 \mathrm{H})$. IR $\left(\mathrm{cm}^{-1}\right): 2962,2879,2785$, 1716, 1689, 1509. SEC: $M_{n}=1.02 \mathrm{~kg} / \mathrm{mol}, M_{w}=$ $1.89 \mathrm{~kg} / \mathrm{mol}, \oplus=1.85$.

\section{LCST determination}

$10 \mathrm{mg}$ of polymer was dissolved in $1.0 \mathrm{~mL}$ of 100 $\mathrm{mM}, \mathrm{pH} 7.0$ or $\mathrm{pH} 8.0$ potassium phosphate buffer. The transmittance was then monitored at $500 \mathrm{~nm}$ using a UV-visible spectrometer as the solution was heated at $2{ }^{\circ} \mathrm{C} / \mathrm{min}$. This measurement was repeated in triplicate.

\section{Block copolymer self-assembly}

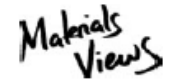

WWW.MATERIALSVIEWS.COM 
Self-assembly was performed using a nanoprecipitation method. ${ }^{52} 8 \mathrm{mg}$ of the block copolymer was dissolved in $1.0 \mathrm{~mL}$ of DMF with stirring overnight. Then, $0.1 \mathrm{~mL}$ of the polymer solution was rapidly injected into $0.9 \mathrm{~mL}$ of ultrapure deionized water while stirring at 700 $\mathrm{rpm}$. Alternatively, $0.9 \mathrm{~mL}$ of ultrapure deionized water was injected dropwise over one min into $0.1 \mathrm{~mL}$ of polymer solution with stirring. After stirring overnight, the suspensions were dialyzed using a $2 \mathrm{~kg} / \mathrm{mol}$ MWCO membrane against ultrapure deionized water $(500 \mathrm{~mL}, 24 \mathrm{~h}$, water changed once at $\sim 12 \mathrm{~h}$ ). Each system was prepared in triplicate.

\section{Assembly degradation studied by Nile red fluorescence}

In a vial, $30 \mu \mathrm{L}$ of $0.1 \mathrm{mg} / \mathrm{mL}$ solution of Nile red in $\mathrm{CH}_{2} \mathrm{Cl}_{2}$ was added and then the solvent was evaporated. Next, $8 \mathrm{mg}$ of the copolymer was added and then dissolved in $1.0 \mathrm{~mL}$ of DMF. Assemblies were then prepared as described above, but dialysed against $100 \mathrm{mM}$ potassium phosphate buffers of $\mathrm{pH} 7.0$ or 8.0. The samples were incubated at 20 or $65^{\circ} \mathrm{C}$. After $30 \mathrm{~min}$, the fluorescence of each system was measured using an excitation wavelength of $540 \mathrm{~nm}$ and recording the emission at $600 \mathrm{~nm}$. The samples were then irradiated with UV light using an ACE Glass photochemistry cabinet containing a mercury light source ( $450 \mathrm{~W}$ bulb, $2.8 \mathrm{~mW} / \mathrm{cm}^{2}$ of UVA radiation) for $30 \mathrm{~min}$. The samples were again incubated at 20 or $65^{\circ} \mathrm{C}$ in the dark. The emission intensity at $600 \mathrm{~nm}$ was measured at select time points over $168 \mathrm{~h}$.

\section{Assembly degradation studied by DLS}

Assemblies were prepared as described above for the Nile red studies, except that no dye was used. The samples were incubated at either 20 or $65{ }^{\circ} \mathrm{C}$. After $30 \mathrm{~min}$, the count rate was measured by DLS, with the attenuator fixed at 9 to obtain the $t=0$ count rate. The samples were then irradiated with UV light as described for the Nile red study, and incubated at either 20 or 65 ${ }^{\circ} \mathrm{C}$ in the dark. The count rate was measured at selected time points over $168 \mathrm{~h}$.

\section{Nanoparticle depolymerization studied by NMR spectroscopy}

In a small vial, $40 \mathrm{mg}$ of the copolymer was dissolved in $1.4 \mathrm{~mL}$ of $100 \mathrm{mM}, \mathrm{pH} 8.0$ potassium phosphate buffered $\mathrm{D}_{2} \mathrm{O}$ and stirred for $30 \mathrm{~min}$. The sample was then split between two NMR tubes with one being incubated at $20^{\circ} \mathrm{C}$ and the other at $65^{\circ} \mathrm{C}$. After $30 \mathrm{~min},{ }^{1} \mathrm{H}$ NMR spectra of the suspensions were obtained. The samples were then irradiated with UV light as described for the DLS study, and incubated at either 20 or $65{ }^{\circ} \mathrm{C}$ in the dark. ${ }^{1} \mathrm{H}$ NMR spectra were obtained at select time points over 28 days. The integration of the peak at $3.26 \mathrm{ppm}$ corresponding to the methyl groups on the cyclic urea derivative (released during depolymerization) relative to that of the peak at $4.17 \mathrm{ppm}$ corresponding to the $-\mathrm{CH}_{2}-\mathrm{O}$ from the PDMAEMA repeat units was used to quantify the extent of depolymerization.

\section{RESULTS AND DISCUSSION}

\section{Polymer design and synthesis}

To investigate the influence of PDMAEMA on the depolymerization of the PCB block, two target polymers were designed (Figure 2). The first polymer PCBuv-PDMAEMA contains a UVresponsive $O$-nitrobenzyl carbonate linker between the polycarbamate and PDMAEMA blocks, while the second (control) polymer

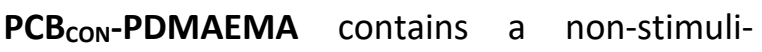
responsive benzyl carbonate.

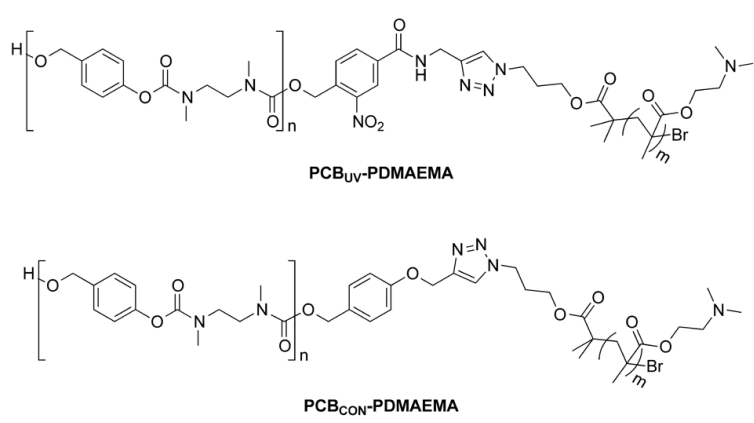

FIGURE 2 Chemical structure of target polymers

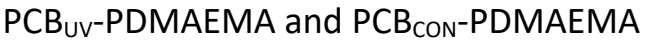


To prepare the two target polymers, two linker end-caps were synthesized, one being sensitive to UV light and the other being not responsive to stimuli. Both end-caps contained alkynes for the conjugation of the PDMAEMA block using a $\mathrm{Cu}(\mathrm{I})$-assisted azide-alkyne cycloaddition (CuAAC). The light-responsive moiety was an onitrobenzyl derivative cleavable at the benzylic site to release uncapped PCB SIP. The unactivated form of the end cap (compound 1) was synthesized in two steps from commercially available 4-(bromomethyl)-3-nitrobenzoic acid and has been previously reported. ${ }^{27}$ The alcohol on 1 was activated with 4-nitrophenyl chloroformate to yield end-cap 2 (Scheme 1a). For the control end-cap, the propargyl etherfunctionalized benzyl alcohol $3^{50}$ was activated with 4-nitrophenyl chloroformate for afford endcap 4 (Scheme 1b).
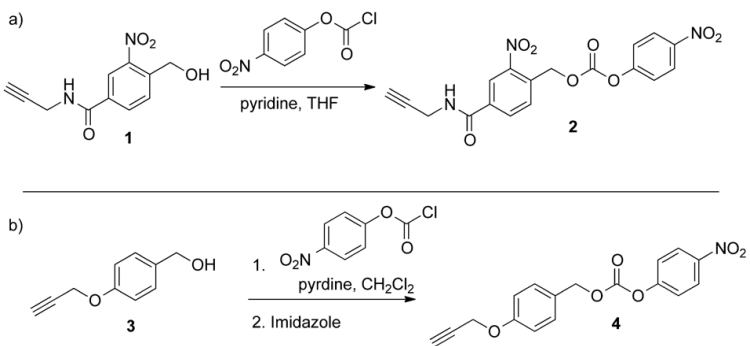

SCHEME 1 Synthesis of linker end-caps: a) UVresponsive end-cap 2 and b) control end-cap 4.

To prepare the PCB blocks, our previously reported monomer precursor $5^{37}$ was first deprotected using $1: 1 \mathrm{CH}_{2} \mathrm{Cl}_{2}$ :TFA to cleave the $t$ butyloxycarbonyl protecting group (Scheme 2). The resulting monomer was then immediately immersed in $\mathrm{CH}_{2} \mathrm{Cl}_{2}$ in the presence of DMAP, $\mathrm{NEt}_{3}$, and 0.05 equiv. of either end-cap 2 or 4 . After $24 \mathrm{~h}$, the polymers were isolated by extraction followed by dialysis to afford $\mathbf{P C B}_{\text {uv }}$

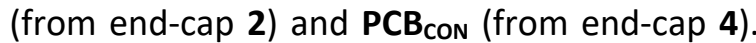
${ }^{1} \mathrm{H}$ NMR spectroscopy indicated that $\mathbf{P C B}_{\mathrm{uv}}$ and $\mathrm{PCB}_{\text {Con }}$ had $\mathrm{M}_{\mathrm{n}}$ values of $4752 \mathrm{~g} \mathrm{~mol}^{-1}$ and $5280 \mathrm{~g}$ $\mathrm{mol}^{-1}$ respectively based on integration of the end-cap peaks relative to those of the backbone repeat units (Figure S5-S6). Size exclusion chromatography in DMF relative to PMMA standards provided an $M_{n}$ of $4640 \mathrm{~g} / \mathrm{mol}$ and $Ð$ of 2.31 for $\mathrm{PCB}_{u v}$ and $a \mathrm{M}_{\mathrm{n}}$ of $5400 \mathrm{~g} / \mathrm{mol}$ and $\emptyset$ of 2.11 for PCB con. These SEC values are in good agreement with those obtained from NMR spectroscopy.

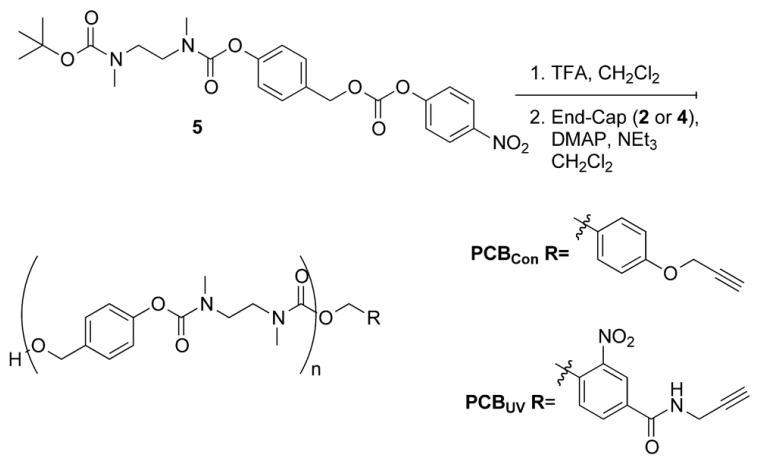

SCHEME 2 Polymerization of PCBuv and PCB Pon. $_{\text {. }}$

To compliment the alkyne on the PCB block, an azide moiety was incorporated at the terminus of the PDMAEMA block. This was achieved using a modified atom-transfer radical-polymerization (ATRP) initiator with an azide functionality (6) (Scheme 3). ${ }^{51}$ The polymer was synthesized using a 20:1 monomer:initiator ratio in the presence of HMTETA and CuBr to yield PDMAEMA-N $\mathrm{N}_{3}$ with an $\mathrm{M}_{\mathrm{n}}$ of $5310 \mathrm{~g} / \mathrm{mol}$ and $\Theta$ of 1.16 .

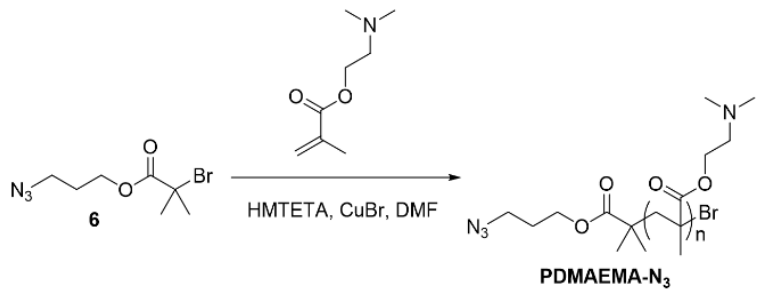

SCHEME 3 Synthesis of PDMAEMA- $\mathbf{N}_{3}$ using an azide-functionalized ATRP initiator.

The PCB and PDMAEMA blocks were then conjugated together via CUAAC using HMTETA and $\mathrm{CuBr}$ to afford PCBuv-PDMAEMA and

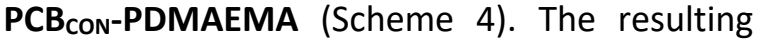
polymers were then purified by dialysis, with EDTA added to remove copper in the first dialysis cycle. ${ }^{1} \mathrm{H}$ NMR spectroscopy showed that the product polymers had peaks corresponding to both the PCB and PDMAEMA blocks (Figures 3a, S7-S9, S10a). SEC showed an increase in the 

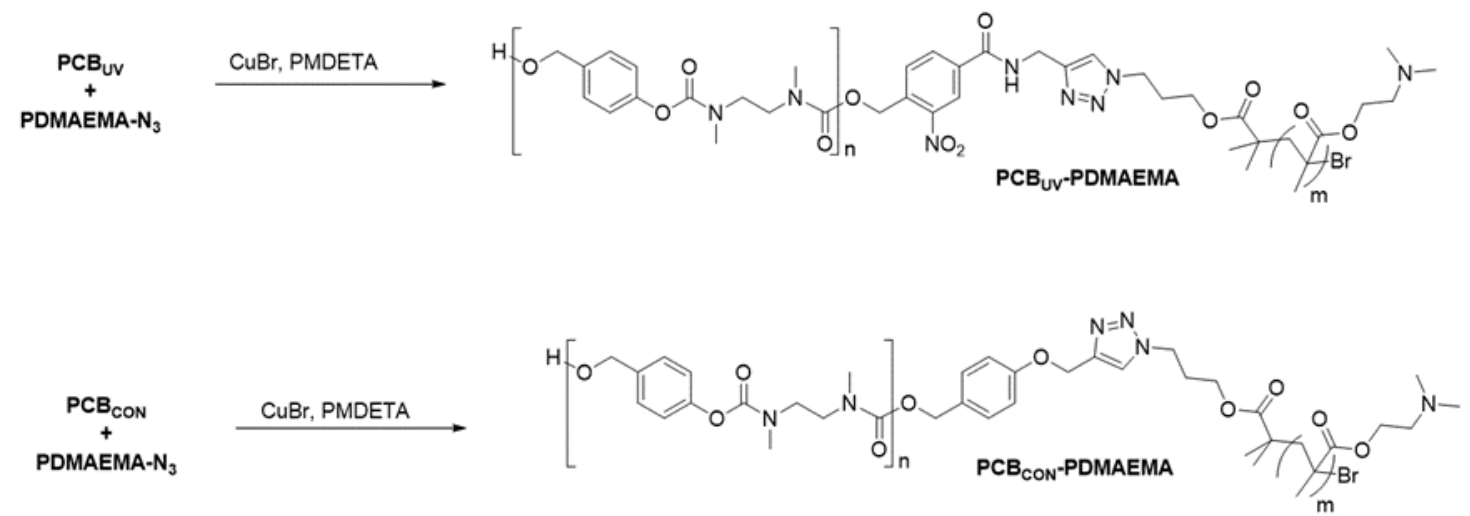

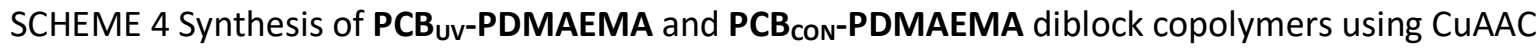

a)
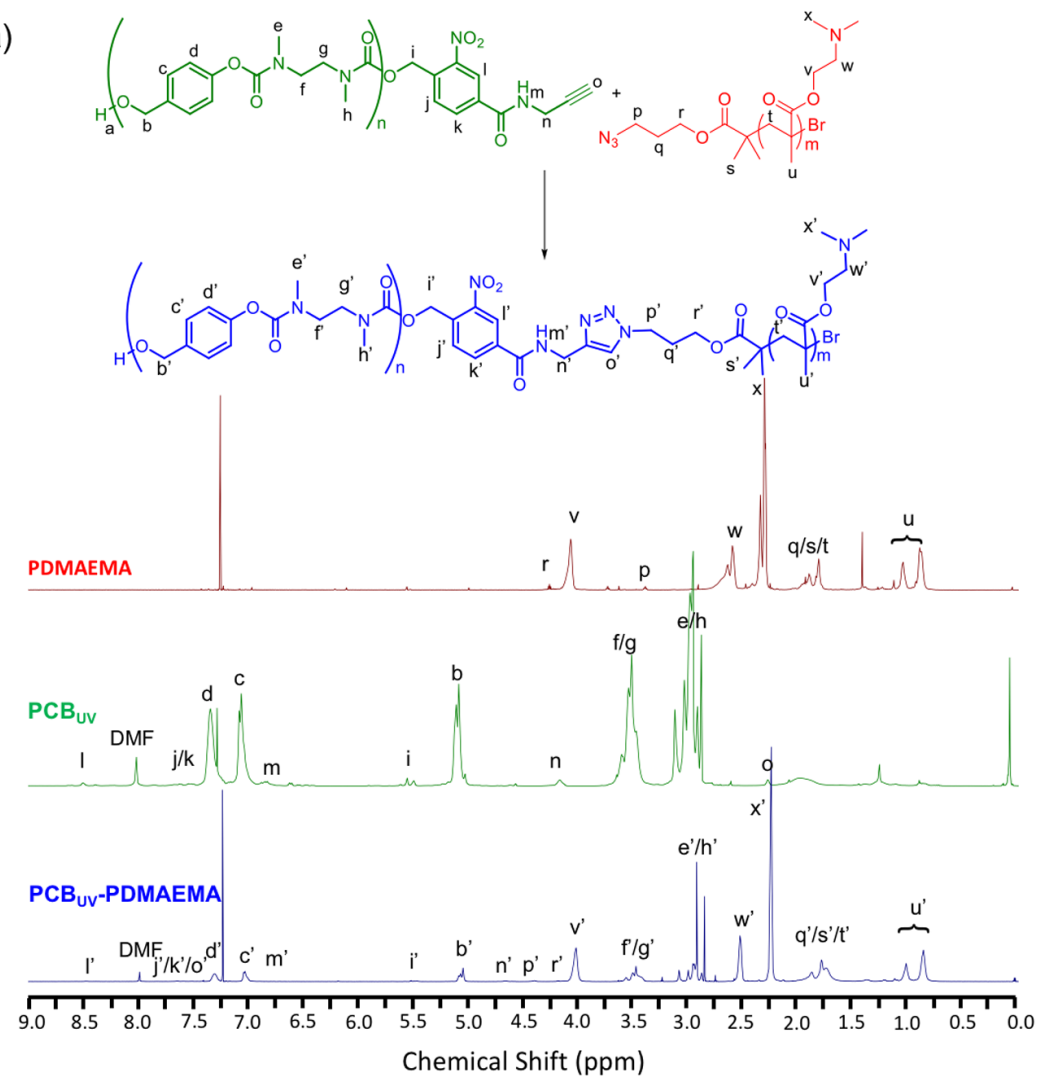

b) PDMAEMA-N ${ }_{3}$ $\mathrm{PCB}_{\mathrm{uv}}$-. . PCBuv-PDMAEMA -.--

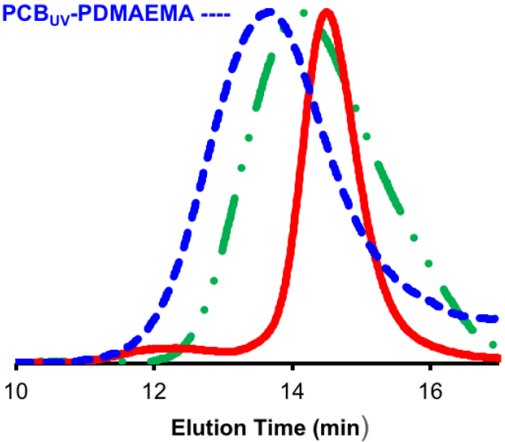

c)

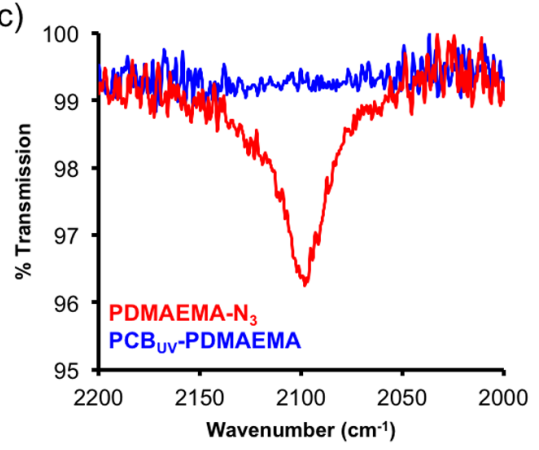

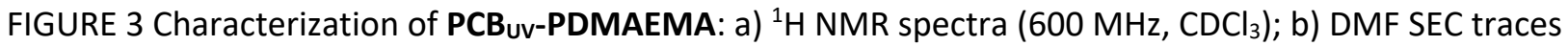
(refractive index detection); c) IR spectra. Figures S7-S9 show additional zoomed NMR spectra.

hydrodynamic volumes of the block copolymers relative to those of the PCB and PDMAEMA, with an $M_{n}$ of $9420 \mathrm{~g} / \mathrm{mol}$ and $\emptyset$ of 1.74 for PCBuvPDMAEMA and an $\mathrm{M}_{\mathrm{n}}$ of $10200 \mathrm{~g} / \mathrm{mol}$ and $\emptyset$ of

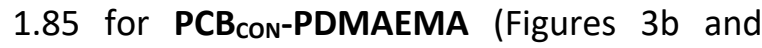
$\mathrm{S10b})$. There was with no evidence of contaminating homopolymer. Finally, IR spectroscopy showed disappearance of the peak at $2100 \mathrm{~cm}^{-1}$ corresponding to the azide stretch, suggesting that the coupling went to completion (Figures 3c and S10c).

\section{LCST measurement for PDMAEMA-N $\mathrm{N}_{3}$}

PDMAEMA is known to exhibit LCST behaviour when above its pKa. ${ }^{45-46}$ The pKa of PDMAEMA- 
$\mathbf{N}_{\mathbf{3}}$ was determined to be 7.2 by performing a titration with $0.5 \mathrm{M} \mathrm{KOH}$ on a solution of PDMAEMA in water (Figure S11). The cloud point of $10 \mathrm{mg} / \mathrm{mL}$ PDMAEMA- $\mathbf{N}_{3}$ was then evaluated in $100 \mathrm{mM} \mathrm{pH} 8.0$ phosphate buffer by measuring the transmittance at $500 \mathrm{~nm}$, while increasing the temperature from 20 to $70^{\circ} \mathrm{C}$ at a rate of $\sim 1{ }^{\circ} \mathrm{C}$ per minute. The cloud point, corresponding to a large sharp drop in transmittance, was found to be $\sim 58^{\circ} \mathrm{C}$ (Figure 4). In contrast, at a concentration of $10 \mathrm{mg} / \mathrm{mL}$ in $100 \mathrm{mM} \mathrm{pH} 7.0$ phosphate buffer, no cloud point was observed.

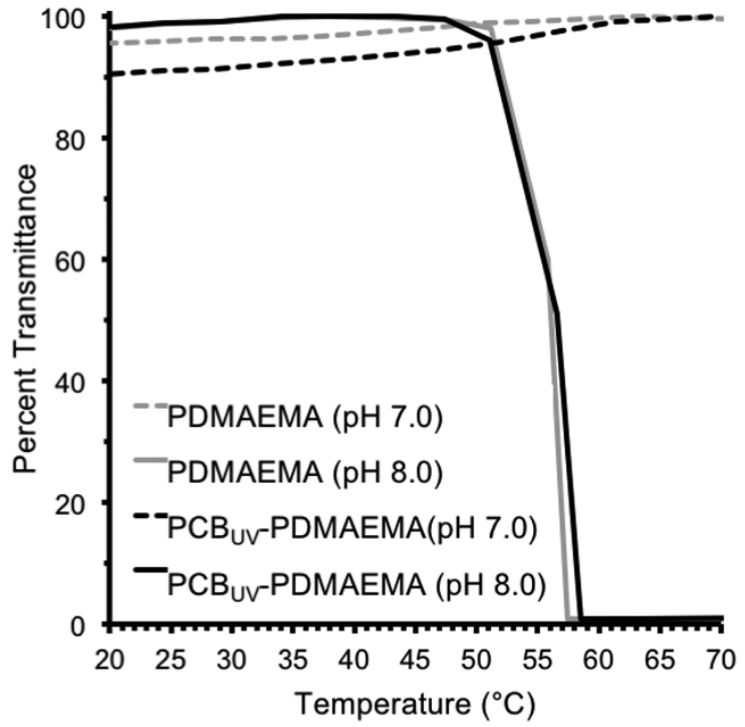

FIGURE 4 Transmittance of a $10 \mathrm{mg} / \mathrm{mL}$ solution/suspension of PDMAEMA- $\mathbf{N}_{3}$ or PCBuvPDMAEMA versus temperature in $100 \mathrm{mM} \mathrm{pH}$ 7.0 or 8.0 phosphate buffer.

\section{Block copolymer self-assembly}

The self-assembly of the amphiphilic diblock copolymers PCBuv-PDMAEMA and PCB con- $^{-}$ PDMAEMA was performed by nanoprecipitation, involving either the addition of a DMF solution of the polymer into water or the addition of water into the DMF polymer solution. DMF was then removed by dialysis. The resulting assemblies were first characterized by DLS and TEM. Assemblies with diameters ranging from $68-95 \mathrm{~nm}$ and polydispersity indices (PDI) of $0.16-0.27$ were obtained based on DLS (Table 1). TEM showed that the assemblies were solid particles with diameters ranging from $\sim 20-50$ $\mathrm{nm}$ (Figure 5). The smaller diameters observed by TEM can be attributed to the dried state of the particles versus the hydrated state measured by DLS. For subsequent studies, the water into DMF method was chosen because of the more similar diameters observed for the two copolymers and their lower PDI values.

TABLE 1 Average micelle diameters and PDI values from DLS.

\begin{tabular}{lcccc}
\hline & \multicolumn{2}{c}{ DMF into Water } & \multicolumn{2}{c}{ Water into DMF } \\
& $\begin{array}{c}\text { Diameter } \\
(\mathrm{nm})\end{array}$ & PDI & $\begin{array}{c}\text { Diameter } \\
(\mathrm{nm})\end{array}$ & PDI \\
& $95 \pm 8$ & 0.27 & $68 \pm 1$ & 0.19 \\
\hline $\begin{array}{l}\text { PCBuv- } \\
\text { PDMAEMA }\end{array}$ & $95 \pm 10.16$ & & \\
\hline $\begin{array}{l}\text { PCBCon- } \\
\text { PDMAEMA }\end{array}$ & $71 \pm 7$ & 0.21 & $68 \pm 1$ & 0.16 \\
\hline
\end{tabular}
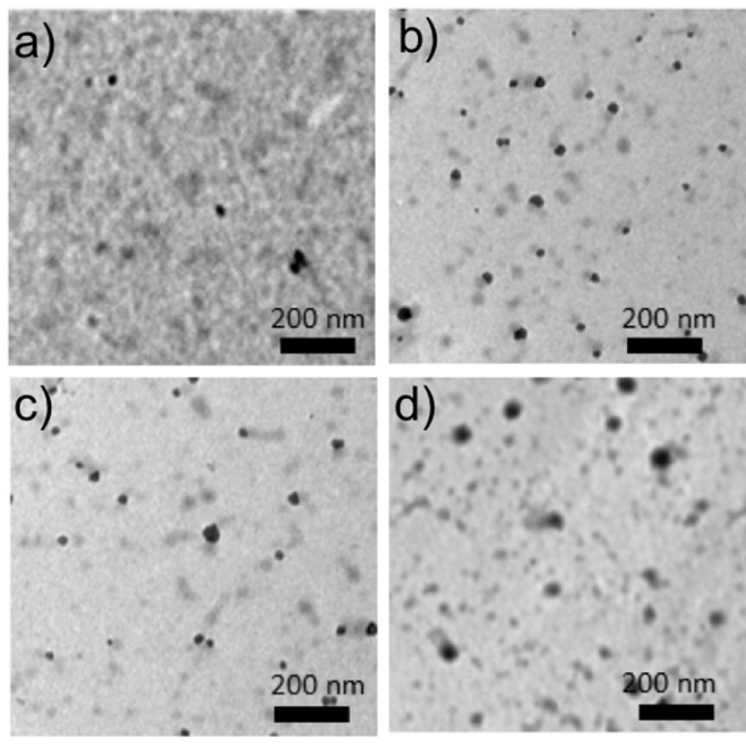

FIGURE 5 TEM images of assemblies formed from a) PCBuv-PDMAEMA via DMF into water; $b$ ) PCB ${ }_{u v}$-PDMAEMA via water into DMF; C) PCB $_{\text {Con }^{-}}$ PDMAEMA via DMF into water; d) PCB $_{\text {Con }^{-}}$ PDMAEMA via water into DMF.

The cloud point of the PCBuv-PDMAEMA assemblies was measured using the same method described above for PDMAEMA-N $\mathbf{N}_{\mathbf{3}}$. The 
cloud point at $\mathrm{pH} 8.0$ was $\sim 58{ }^{\circ} \mathrm{C}$, the same temperature determined for PDMAEMA- $\mathbf{N}_{3}$, and no cloud point was detected at pH 7.0 (Figure 4).

\section{Depolymerization of the assemblies}

First, the depolymerization of the assemblies was investigated by florescence spectroscopy using Nile red as an encapsulated probe molecule. Nile red fluoresces strongly in the hydrophobic cores of particles, but undergoes extensive aggregation and quenching in water. ${ }^{53-}$ ${ }^{54}$ Thus, a decrease in Nile red fluorescence can correspond to its release from particles into the aqueous environment as they degrade. The micelles were prepared by the water into DMF nanoprecipitation method with the addition of 2 $w t \%$ Nile red relative to polymer in the DMF. The resulting assemblies were dialysed against a 100 $\mathrm{mM}$ phosphate buffer of $\mathrm{pH} 7.0$ or 8.0. Before the stimulus was applied, a sample of each system was equilibrated at room temperature $\left(20^{\circ} \mathrm{C}\right)$ or above the LCST $\left(65^{\circ} \mathrm{C}\right)$ and the initial Nile red fluorescence was measured. The fluorescence of the equivalent concentration of Nile red in buffer without polymers was $~ 12 \%$ that of the Nile red loaded into assemblies. UV light was then applied to both the $\mathbf{P C B}_{u^{-}}$ PDMAEMA and PCB CON-PDMAEMA assemblies and they were incubated at either 20 or $65^{\circ} \mathrm{C}$. The fluorescence was measured at various time points over a period of $168 \mathrm{~h}$ ( 7 days).

Comparing the PCBuv-PDMAEMA and PCB $_{\text {Con }^{-}}$ PDMAEMA at $20{ }^{\circ} \mathrm{C}$, the stimuli-responsive polymer exhibited a decrease in fluorescence of $\sim 30 \%$ at $\mathrm{pH} 7.0$ and $\sim 20 \%$ at $\mathrm{pH} 8.0$, whereas the control exhibited only a negligible decrease (< 10\%) (Figure 6). This result suggests that stimuliresponsive depolymerization occurred and that background degradation of the control was minimal. At $65{ }^{\circ} \mathrm{C}$, the decrease in Nile red fluorescence was also greater for $\mathbf{P C B}_{\text {uv- }}$

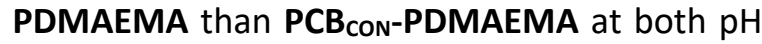
7.0 and 8.0 for most time points. This suggests that stimuli-responsive depolymerization was still occurring at this temperature. Comparing $\mathrm{pH}$ 7.0 and $\mathrm{pH} 8.0$ at $65^{\circ} \mathrm{C}$ for PCBuv-PDMAEMA, it appears that the release was faster at $\mathrm{pH} 7.0$ over the first $\sim 75 \mathrm{~h}$. As the cyclization and elimination reactions involved in depolymerization should normally be faster at $\mathrm{pH} 8.0$ than $7.0,{ }^{37}$ this suggests a possible slowing of the depolymerization rate due to PDMAEMA chain collapse at $\mathrm{pH} 8.0$ and $65^{\circ} \mathrm{C}$. However, by $100 \mathrm{~h}$, the systems at the two pHs were very similar, with $\sim 60 \%$ decrease in Nile red fluorescence. It was also noted above that the fluorescence decrease was slightly more at $\mathrm{pH}$ 7.0 even at $20{ }^{\circ} \mathrm{C}$, so this might relate to the overall hydrophilicity of the PDMAEMA and resulting water access to the particle cores as opposed to chain collapse specifically. The

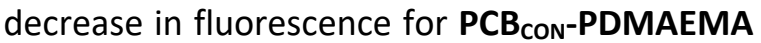
was $\sim 40 \%$ over $168 \mathrm{~h}$ at both $\mathrm{pHs}$, indicating that background degradation of the assemblies also occurred at $65^{\circ} \mathrm{C}$. This degradation can likely be attributed to cleavage of the carbonate linkage on the end-cap linker or cleavage of backbone carbamate bonds in the PCB block. Either of these cleavages would result in depolymerization of $\mathrm{PCB}$, thereby amplifying the non-specific degradation. In addition, it is clear that for each system the release of Nile red was faster at $65{ }^{\circ} \mathrm{C}$, suggesting that the rate acceleration resulting from the temperature increase dominated over the environmental effects associated with PDMAEMA chain collapse. 
a)

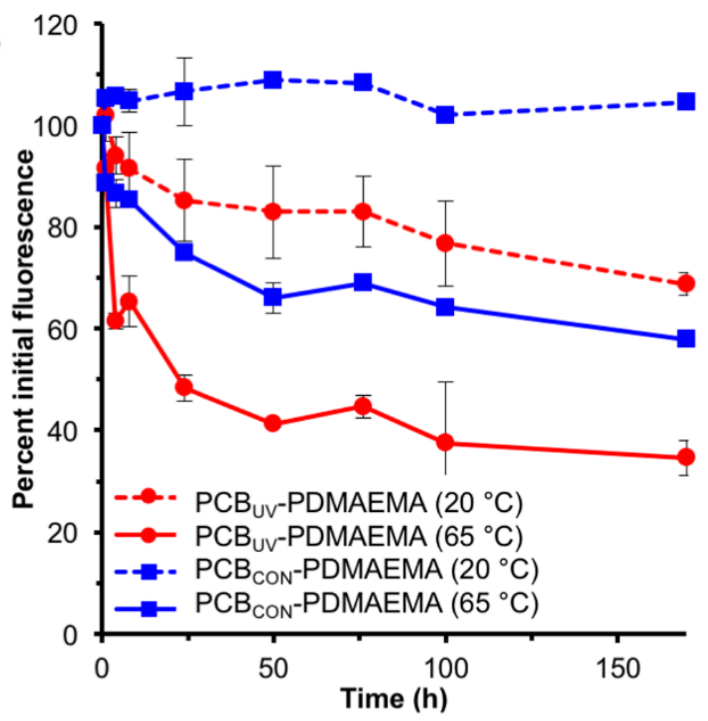

b)

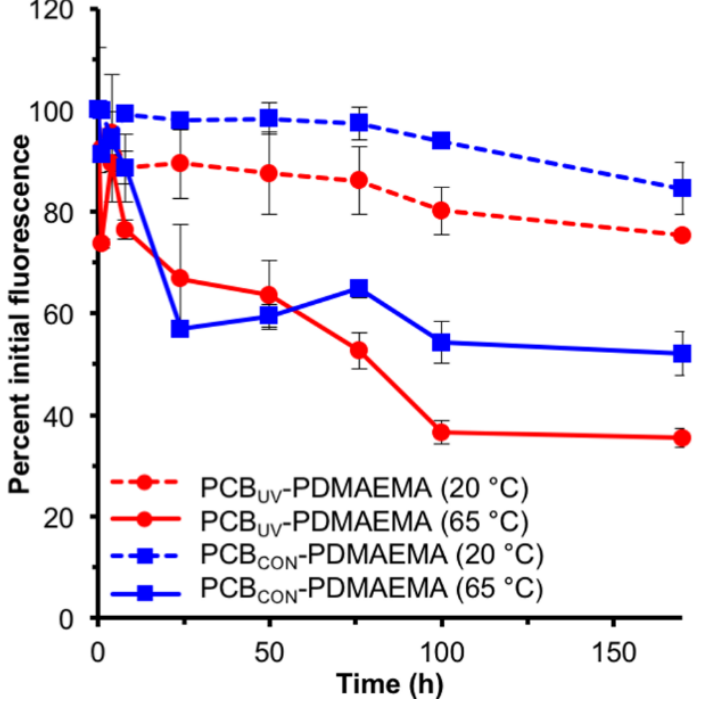

FIGURE 6 Change in the fluorescence of Nile red encapsulated in PCBuv-PDMAEMA or PCB $_{\text {CON }^{-}}$ PDMAEMA assemblies following irradiation with UV light at a) pH 7.0 and b) pH $8.0(100 \mathrm{mM}$ phosphate buffer).

DLS can also provide an indication of assembly degradation because the scattered light intensity, measured as the mean count rate, is proportional to the number of scattering species and their masses. Depolymerization of the assemblies was expected to result in a decrease in the mean count rate over time. The particles were again assembled as they were in the florescence study, at $\mathrm{pH} 7.0$ or 8.0 , but without Nile red. They were then irradiated with UV light and incubated at either 20 or $65^{\circ} \mathrm{C}$. At $20^{\circ} \mathrm{C}$, a minimal change in count rate was observed over $180 \mathrm{~h}$ for PCBuv-PDMAEMA and PCB Con- $^{-}$ PDMAEMA at both $\mathrm{pH}$ values (Figure 7). While depolymerization was expected to result in a decrease in count rate due to disintegration of the assemblies, the situation may be more complicated. Upon cleavage of the soluble PDMAEMA blocks from the assembly coronas, the resulting hydrophobic particles can aggregate at the same time as depolymerizing, which may result in a net negligible effect on the count rate. In contrast, at $65{ }^{\circ} \mathrm{C}$, all assemblies underwent a significant decrease in scattering count rate of $30-60 \%$. At pH 7.0, where the PDMAEMA should remain soluble, PCBuv- $^{-}$ PDMAEMA underwent a larger decrease than

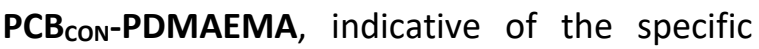
triggering that was observed for the Nile red study. In contrast, at $\mathrm{pH}$ 8.0, where the PDMAEMA exhibits an LCST, the count rate was erratic for both systems. This can likely be attributed to aggregation of the PDMAEMA with itself and with the remaining PCB cores as they were depolymerizing. This aggregation would contribute to an increase in count rate, while depolymerization would contribute to a decrease.

In addition to the count rates, the volume distributions of the assemblies from DLS were also examined. As shown in Figures S12-S13, the diameters of the main peaks did not change substantially in any case. However, peaks corresponding to aggregates were observed for PCBuv-PDMAEMA under all conditions, and for $\mathrm{PCB}_{\text {con-PDMAEMA at } \mathrm{pH}} 8.0$ and $65^{\circ} \mathrm{C}$. These results are consistent with the above interpretation involving a combination of aggregation and depolymerization. Thus, there is an effect arising from the PDMAEMA LCST, but it is difficult to elucidate. Overall, the accelerated reactions at $65{ }^{\circ} \mathrm{C}$ resulted in more rapid degradation of the assemblies. 
a)
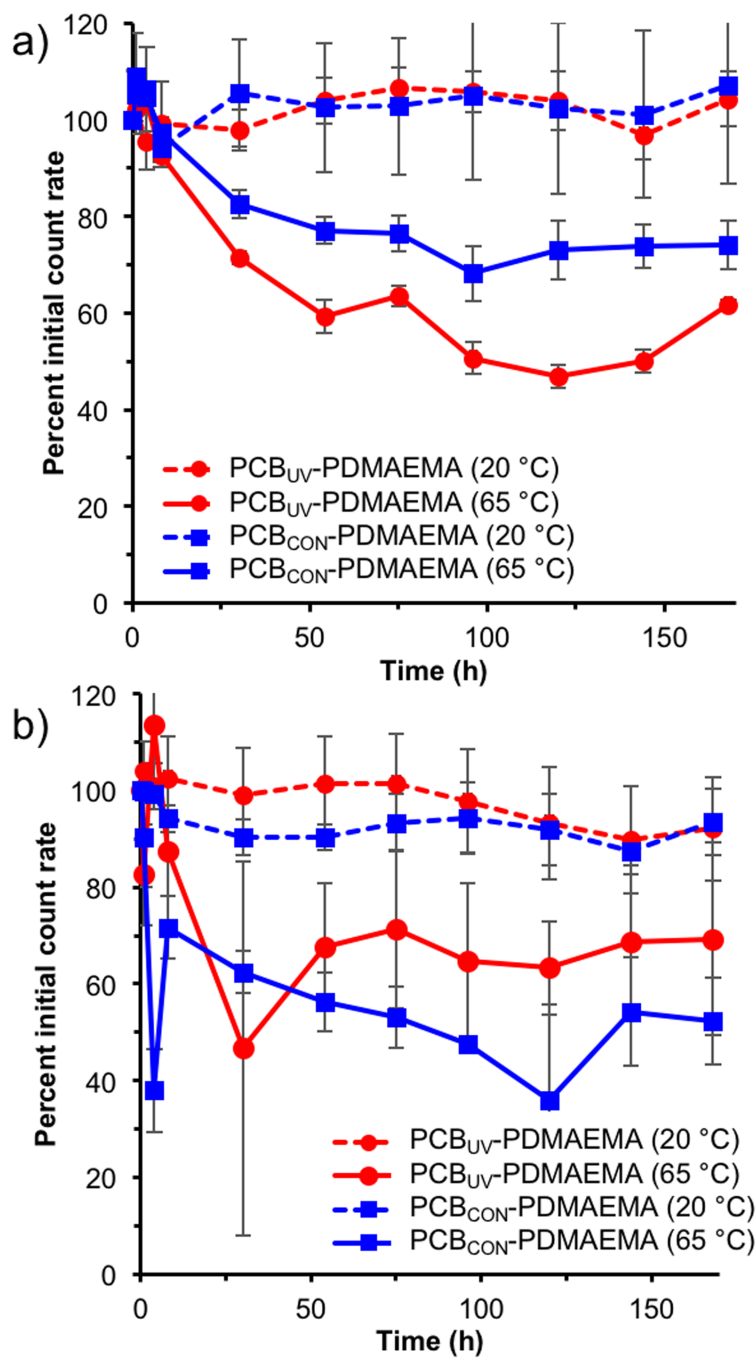

FIGURE 7 Change in DLS count rate for PCB $_{\text {uv }}$ PDMAEMA or PCB CON-PDMAEMA assemblies following irradiation with UV light at a) $\mathrm{pH} 7.0$ and b) pH 8.0 (100 mM phosphate buffer).

${ }^{1} \mathrm{H}$ NMR spectroscopy was used to confirm the depolymerization of the SIP block at $\mathrm{pH} 8.0$ (where the LCST was be observed) to support data from the Nile red and DLS studies. For this, assemblies were obtained by sonication of the PCB ${ }_{\text {uv-PDMAEMA or PCB }}$ Con-PDMAEMA in 100 $\mathrm{mM}, \mathrm{pH} 8.0$ phosphate buffered $\mathrm{D}_{2} \mathrm{O}$. Initial spectra were obtained, and only peaks corresponding to the PDMAEMA blocks were observed. Peaks corresponding to the PCB block were attenuated as this polymer was packed into the assembly core, resulting in long proton relaxation times (Figures S14-S17). Samples were then irradiated with UV light and incubated at either 20 or $65{ }^{\circ} \mathrm{C}$. Upon depolymerization, peaks corresponding to the depolymerization products emerged (Figures S14-S17). The emerging peak at $3.26 \mathrm{ppm}$ from the cyclic urea formed by the depolymerization of the PCB block was integrated against the peak at $4.17 \mathrm{ppm}$ corresponding to the $\mathrm{CH}_{2}$ adjacent to the ester on the PDMAEMA block. Over 4 weeks at $20^{\circ} \mathrm{C}$, more rapid depolymerization was observed for PCBuv-PDMAEMA than for PCB Con-PDMAEMA, confirming that it occurred in a stimuliresponsive manner (Figure 8). However, at $65^{\circ} \mathrm{C}$ there was less difference between the behavior of the two polymers, indicating that the elevated temperatures needed to be above PDMAEMA's LCST resulted in a high level of background depolymerization. This result was consistent with those of the Nile red and DLS studies.

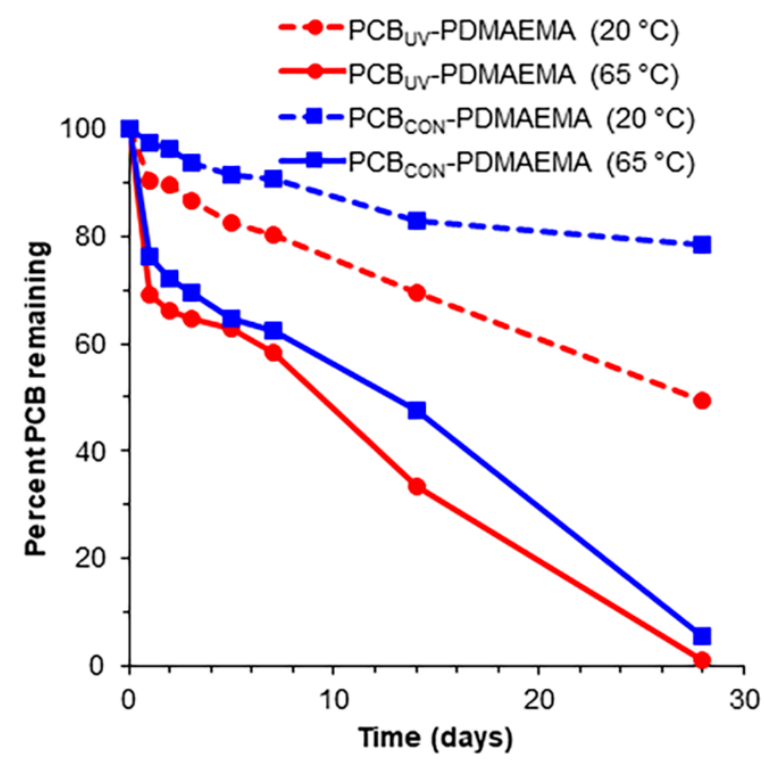

FIGURE 8 Depolymerization rates measured by ${ }^{1} \mathrm{H}$ NMR spectroscopy for the PCB blocks of PCB ${ }_{\text {Uv-PDMAEMA and PCB }}$ Con-PDMAEMA after irradiation and incubation in $100 \mathrm{mM}, \mathrm{pH} 8.0$ phosphate buffered $\mathrm{D}_{2} \mathrm{O}$ at either 20 or $65^{\circ} \mathrm{C}$.

\section{CONCLUSIONS}

In conclusion, we successfully synthesized PCBPDMAEMA block copolymers containing a hydrophobic SIP block and a $\mathrm{pH}$ - and thermoresponsive hydrophilic block. Both a UV light- 
responsive system PCBuv-PDMAEMA and a control system PCB $_{\text {con-PDMAEMA were }}$ prepared and studied. Both block copolymers were self-assembled via nanoprecipitation to afford solid particles with diameters of $\sim 70 \mathrm{~nm}$. The assemblies had an LCST at the same temperature $\left(\sim 58{ }^{\circ} \mathrm{C}\right)$ as the PDMAEMA- $\mathbf{N}_{\mathbf{3}}$ homopolymer. Depolymerization of the assemblies in response to UV light irradiation was studied using Nile red as a fluorescent probe, and by DLS and NMR spectroscopy. In each case, stimuli-responsive degradation was observed at $20{ }^{\circ} \mathrm{C}$. A possible effect of PDMAEMA solubility change or chain collapse on the depolymerisation rate was suggested by the Nile red data at $\mathrm{pH} 8.0$, but at $65{ }^{\circ} \mathrm{C}$ there was significant background degradation of the PCB, reducing the differences in the behavior of

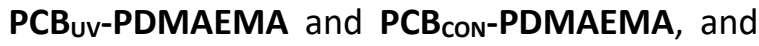
masking this effect. In addition, as the effects of elevated reaction rates dominated over any environmental effects from PDMAEMA chain collapse above the LCST, the depolymerizations were always faster at higher temperatures (Figure 9). In the future, it may be possible to observe the effects of chain collapse more clearly by using an SIP lacking non-specific degradation pathways or by using a thermoresponsive polymer with a lower LCST so that depolymerization can be studied with chain collapse at lower temperatures.

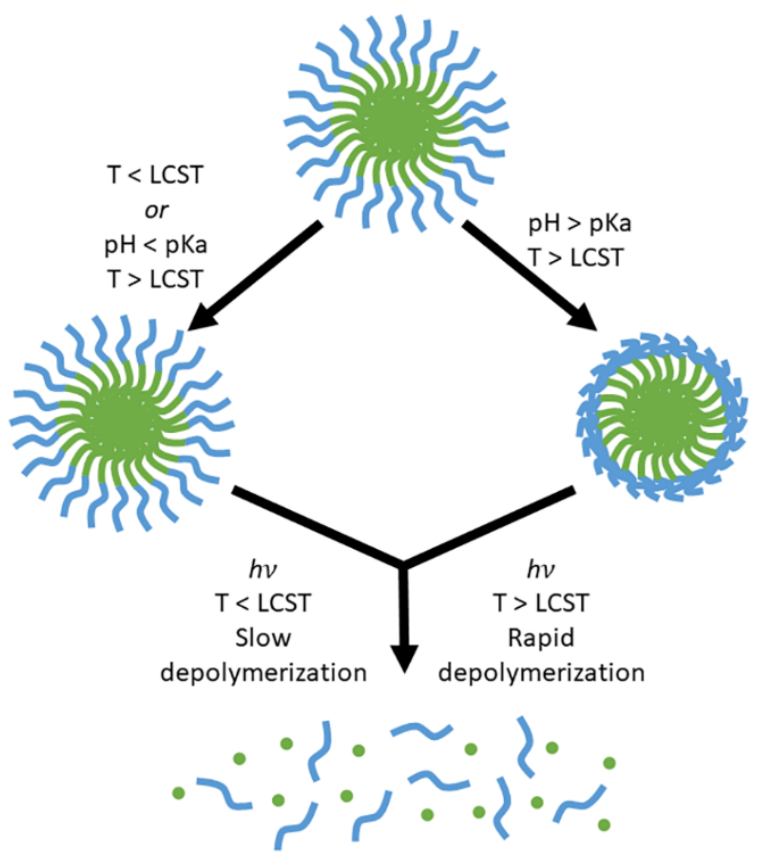

FIGURE 9 Out of the three stimuli investigated $(\mathrm{pH}, \quad \mathrm{UV}$ and temperature) the elevated temperature dominated the depolymerization behaviour, masking other environmental factors to a great extent.

\section{ACKNOWLEDGEMENTS}

The authors thank the Natural Sciences and Engineering Research Council of Canada (Discovery Grant 2016-04636 and Canada Graduate Scholarship for REY) for funding this work.

\section{REFERENCES AND NOTES}

1. R. Langer and J. P. Vacanti, Science 1993, 260, 920.

2. M. Vert, G. Schwach, R. Engel and J. Coudane, J. Controlled Release 1998, $53,85$.

3. B. Tyler, D. Gullotti, A. Mangraviti, T. Utsuki and H. Brem, Adv. Drug Delivery Rev. 2016, 107, 163.

4. G. G. Pitt, M. M. Gratzl, G. L. Kimmel, J. Surles and A. Sohindler, Biomaterials 1981, 2, 215. 
5. I. Bala, S. Hariharan and M. N. V. R. Kumar, Crit. Rev. Therap. Drug Carrier Syst. 2004, 21, 387.

6. C. E. Astete and C. M. Sabliov, J. Biomater. Sci.: Polym. Ed. 2006, 17, 247.

7. R. S. Bezwada, D. D. Jamiolkowski, I.-Y. Lee, V. Agarwal, J. Persivale, S. TrenkaBenthin, M. Erneta, J. Suryadevara, A. Yang and S. Liu, Biomaterials 1995, 16, 1141.

8. M. J. Heffernan and N. Murthy, Bioconjugate Chem. 2005, 16, 1340.

9. S. C. Yang, M. Bhide, I. N. Crispe, R. H. Pierce and N. Murthy, Bioconjugate Chem. 2008, 19, 1164.

10. X. Duan, Y. L. Wu, M. S. Ma, J. J. Du, S. Zhang, $\mathrm{H}$. Chen and J. Kong, J. Mater. Sci. 2017, 52, 9430.

11. E. Emilitri, E. Ranucci and P. Ferruti, J. Polym. Sci. Part A: Polym. Chem. 2005, 43, 1404.

12. N. V. Tsarevsky and K. Matyjaszewski, Macromolecules 2002, 35, 9009.

13. C. Li, J. Madsen, S. P. Armes and A. L. Lewis, Angew. Chem. Int. Ed. 2006, 45, 3510.

14. J. F. Quinn, M. R. Whittaker and T. P. Davis, Polym. Chem. 2017, 8, 97.

15. S. Kumar, J.-F. Allard, D. Morris, Y. L. Dory, M. Lepage and Y. Zhao, J. Mater. Chem. 2012, 22, 7252.

16. S. Honda, N. Tanaka and T. Toyota, J. Polym. Sci., Part A: Polym. Chem. 2018, $56,9$.

17. H. Zhao, E. S. Sterner, E. B. Coughlin and P. Theato, Macromolecules 2012, 45, 1723.

18. J. Olejniczak, M. Chan and A. Almutairi, Macromolecules 2015, 48, 3166.

19. A. P. Goodwin, J. L. Mynar, Y. Ma, G. R. Fleming and J. M. J. Fréchet, J. Am. Chem. Soc. 2005, 127, 9952.

20. M. E. Roth, O. Green, S. Gnaim and D. Shabat, Chem. Rev. 2016, 116, 1309.

21. A. D. Wong, M. A. DeWit and E. R. Gillies, Adv. Drug Delivery Rev. 2012, 64, 1031.
22. S. T. Phillips and A. M. DiLauro, ACS Macro Lett. 2014, 3, 298.

23. B. Fan, J. F. Trant and E. R. Gillies, Macromolecules 2016, 49, 9309.

24. G. Liu, X. Wang, J. Hu, G. Zhang and S. Liu, J. Am. Chem. Soc. 2014, 136, 7492.

25. M. A. Dewit, A. Beaton and E. R. Gillies, J. Polym. Sci. Part A: Polym. Chem. 2010, 48, 3977.

26. B. Fan, J. F. Trant, G. Hemery, O. Sandre and E. R. Gillies, Chem. Commun. 2017, 53, 12068.

27. B. Fan, J. F. Trant, A. D. Wong and E. R. Gillies, J. Am. Chem. Soc. 2014, 136, 10116.

28. C. de Gracia Lux, C. L. McFearin, S. JoshiBarr, J. Sankaranarayanan, N. Fomina and A. Almutairi, ACS Macro Lett. 2012, $1,922$.

29. A. M. DiLauro, J. S. Robbins and S. T. Phillips, Macromolecules 2013, 46, 2963.

30. A. M. DiLauro, H. Zhang, M. S. Baker, F. Wong, A. Sen and S. T. Phillips, Macromolecules 2013, 46, 7257.

31. J. A. Kaitz, C. E. Diesendruck and J. S. Moore, J. Am. Chem. Soc. 2013, 135, 12755.

32. J. A. Kaitz and J. S. Moore, Macromolecules 2013, 46, 608.

33. S. Tang, L. Tang, X. Lu, H. Liu and J. S. Moore, J. Am. Chem. Soc. 2018, 140, 94.

34. B. Fan, J. F. Trant, R. E. Yardley, A. J. Pickering, F. Lagugné-Labarthet and $\mathrm{E}$. R. Gillies, Macromolecules 2016, 49, 7196.

35. B. Fan and E. R. Gillies, Mol. Pharmaceutics 2017, 14, 2548.

36. A. Sagi, R. Weinstain, N. Karton and D. Shabat, J. Am. Chem. Soc. 2008, 130, 5434.

37. M. A. DeWit and E. R. Gillies, J. Am. Chem. Soc. 2009, 131, 18327.

38. G. G. Lewis, J. S. Robbins and S. T. Phillips, Macromolecules 2013, 46, 5177.

39. J. S. Robbins, K. M. Schmid and S. T. Phillips, J. Org. Chem. 2013, 78, 3159. 
40. R. A. McBride and E. R. Gillies, Macromolecules 2013, 46, 5157.

41. A. D. Wong, T. M. Güngör and E. R. Gillies, ACS Macro Lett. 2014, 3, 1191.

42. M. G. Olah, J. S. Robbins, M. S. Baker and S. T. Phillips, Macromolecules 2013, 46, 5924.

43. M. Heskins and J. E. Guillet, J. Macromol. Sci., Part A: Pure Appl. Chem. 1968, 2, 1441.

44. H. G. Schild, Prog. Polym. Sci. 1992, 17, 163.

45. F. A. Plamper, M. Ruppel, A. Schmalz, O. Borisov, M. Ballauff and A. H. E. Müller, Macromolecules 2007, 40, 8361.

46. J. Niskanen, C. Wu, M. Ostrowski, G. G. Fuller, S. Hietala and H. Tenhu, Macromolecules 2013, 46, 2331.

47. Y. Hu, V. Darcos, S. Monge, S. Li, Y. Zhou and F. Su, Int. J. Pharm. 2014, 476, 31.

48. Y. Mai and A. Eisenberg, Chem. Soc. Rev. 2012, 41, 5969.

49. G. Liu, G. Zhang, J. Hu, X. Wang, M. Zhu and S. Liu, J. Am. Chem. Soc. 2015, 137, 11645

50. B. Rubio-Ruiz, J. T. Weiss and A. UncitiBroceta, J. Med. Chem. 2016, 59, 9974.

51. L. Wu, U. Glebe and A. Böker, Macromol. Rapid Commun. 2017, 38, 1600475.

52. E. Lepeltier, C. Bourgaux and P. Couvreur, Adv. Drug Delivery Rev. 2014, $71,86$.

53. P. Greenspan, E. P. Mayer and S. D. Fowler, J. Cell Biol. 1985, 100, 965.

54. M. M. G. Krishna, J. Phys. Chem. A 1999, 103, 3589. 


\section{GRAPHICAL ABSTRACT}

Rebecca E. Yardley, Elizabeth R. Gillies

\section{Multi-stimuli-responsive Self-immolative Polymer Assemblies}

Copolymers composed of a self-immolative polycarbamate (PCB) block and a thermo- and pHresponsive poly(2-(dimethylamino)ethyl methacrylate) (PDMAEMA) block conjugated by a lightresponsive linker end-cap were synthesized and assembled into nanoparticles sensitive to light, $\mathrm{pH}$, and temperature. Depolymerization of the assemblies was studied at $20^{\circ} \mathrm{C}$, below the lower critical solution temperature (LCST) of PDMAEMA, and at $65^{\circ} \mathrm{C}$, above the LCST to elucidate the effects of temperature and PDMAEMA collapse on the depolymerisation of the PCB.

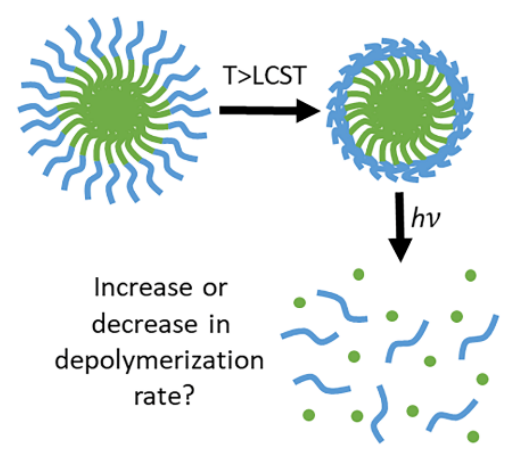

